\title{
Investigating Effect of Ca Content on Electrostatic Potential Energy (EP), Critical Temperature $\left(T_{c}\right)$ and Structure Parameters on $\mathrm{Y}_{1-x} \mathrm{Ca}_{x} \mathrm{Ba}_{2} \mathrm{Cu}_{3} \mathrm{O}_{7-\delta}$ Superconductor
}

\author{
Bassam M. Mustafa Abbas H. Rostam \\ Department of Physics / College of Science / University of Mosul
}

(Received 28/11/2013;Accepted 10/3/2014)

\begin{abstract}
In this paper the effect of $\mathrm{Ca}$ content in $\mathrm{Y}_{1-x} \mathrm{Ca}_{x} \mathrm{Ba}_{2} \mathrm{Cu}_{3} \mathrm{O}_{7-\delta}$ and the relation between electrostatic potential energy, critical temperature $\left(T_{c}\right)$, lattice parameters $\left(a_{p a}\right)$, volume lattice parameter $\left(V_{p a}\right)$, orthorhombicity, and the hole concentration is investigated by applying the ionic model to calculate the change in the electrostatic potential due to increasing the Ca content in the compound in $\mathrm{Y}_{1-x} \mathrm{Ca}_{x} \mathrm{Ba}_{2} \mathrm{Cu}_{3} \mathrm{O}_{7-\delta}$. It is found that $\mathrm{Ca}^{2+}$ substitution for $\mathrm{Y}^{3+}$ leads to increase EP caused by increased ion volume and decrease of charge, this explains changes of superconducting structure parameters such as: lattice parameter $\left(a_{p a}\right)$, volume lattice parameter $\left(V_{p a}\right)$, orthorhombicity. Furthermore $\left(T_{c}\right)$ decreases with increasing Ca content due to increase of EP which leads to change of the crystal structure and thus decreasing oxygen content and as a result decreasing of $\left(T_{c}\right)$. Finally considering all above effects the increase of EP will increase the superconducting current.
\end{abstract}

Keywords: Electrostatic potential energy, Ca content, superconductor compounds.

$$
\begin{aligned}
& \text { استقصاء تأثير محتوى الكالسيوم على EP و (T }) \text { ومعلم التركيب للمركب الفائق التوصيل } \\
& \mathrm{Y}_{1-x} \mathrm{Ca}_{x} \mathrm{Ba}_{2} \mathrm{Cu}_{3} \mathrm{O}_{7-\delta}
\end{aligned}
$$

\section{الملخص}

في هذا البحث تمت دراسة تأثثر محتوى الكالسيوم في المركب الكهروستاتيكي (T) )، والمعلم الثبيكي، والصفة المعينية متعامدة المحاور و معلم الحجم وتأثنيره على تركيز الفجوات. وذللك

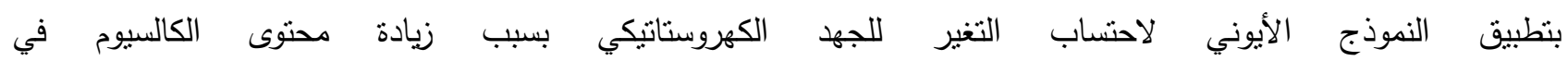

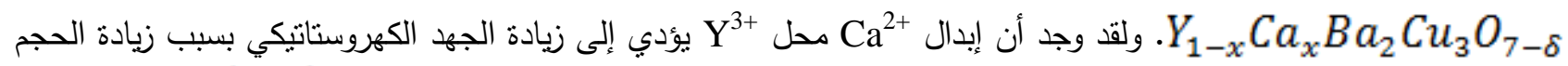
الايوني و نقصان الثحنة. وهذا يفسر التغير في المعالم التركيبية فائقة التوصيل مثل: المعلم الثبيكي (a

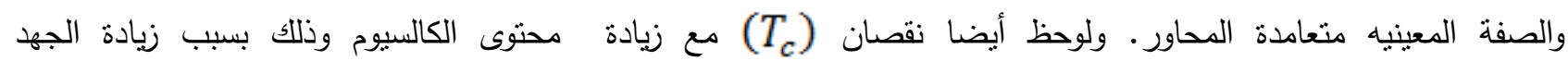
الكهروستاتيكي والذي أدى ارتخاء التركيب البلوري وبالتالي نقصان محتوى الأوكسجين وهذا أدى إلى نقصان (T) (T) .

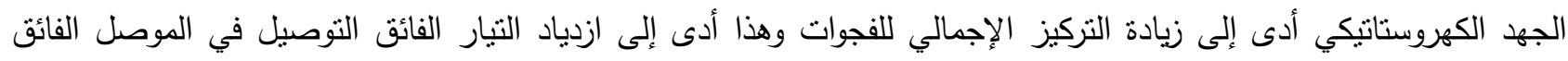

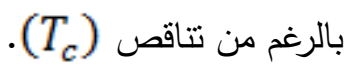

$$
\text { الكلمات الدالة: طاقة الجهد الكهروستاتكي، نركيز الكالسيوم والمركبات الفائق التوصيل. }
$$




\section{INTRODUCTION}

Ever since $\mathrm{Y}_{123}$ the first discovery in 1986 an enormous work has done toward experimental and theoretical investigation about structure and conduction in this compound. However, till now researches are active in this field (Wu et al., 1998), (Sedky and Abu-Ziad, 2010). In spite of the great efforts spent by researches in order to explain conduction in $Y_{123}$, till now there is no agreement about model for conduction in $\mathrm{Y}_{123}$ compound. Efforts on substitution in high temperature superconductors (HTSC) from their initial discovery lead to great improvement in $\left(T_{c}\right)$ and to the discoveries of new high temperature superconductors, HTSC (Zhao, 2005), ( McCormack and de Fontaine., 1992).

Substitution of $\mathrm{Ca}^{2+}$ instead of $\mathrm{Y}^{3+}$ ion in $\mathrm{YBa}_{2} \mathrm{Cu}_{3} \mathrm{O}_{7-\delta}$, with comparable ionic radii, with amount of $\mathrm{Ca}^{2+}$ content ( 0 to 0.3 ), has the effect of increase of superconducting current in the compound; however, the transition temperature decreases (Naqib et al., 2009), (Schlachter et al.,1999). On the other side, substitution of $\mathrm{Ca}^{2+}$ in $\mathrm{YBa}_{2} \mathrm{Cu}_{3} \mathrm{O}_{7-\delta}$ does not change the average valence of $\mathrm{Cu}$ ion, but the amount of oxygen deficiency $\delta$ increases linearly with $\mathrm{Ca}$ content (Iguchi et al., 1988). $\mathrm{Ca}^{+2}$ substitution for $\mathrm{Y}^{+3}$ increases the overall hole concentration. Hole doping is very low for highly oxygenated samples, while it is quite significant for oxygen deficient samples (Liyanawaduge et al., 2012). Introducing calcium reside in $\mathrm{CuO}_{2}$ planes, lead to a competition mechanism of the hole density in $\mathrm{CuO}_{2}$ planes between Ca doping and oxygen depletion (Jian et al., 1998).

Great efforts till now try to study effects of substitution of $\mathrm{Ca}^{2+}$ in $\mathrm{Y}_{123}$ on the properties like the lattice parameters orthorhombicity, and $\left(\mathrm{T}_{c}\right)$ in superconductor $\mathrm{Y}_{1-x} \mathrm{Ca}_{x} \mathrm{Ba}_{2} \mathrm{Cu}_{3} \mathrm{O}_{7-\delta}$ (Giri et al., 2005), (Han et al., 2001).

The purpose of this research is to apply the ionic model to calculate the change in the electrostatic potential due to increasing the $\mathrm{Ca}$ content in the compound in $\mathrm{Y}_{1-x} \mathrm{Ca}_{x} \mathrm{Ba}_{2} \mathrm{Cu}_{3} \mathrm{O}_{7-\delta}$ and to prove that there is a relation between changing $\mathrm{EP}$ and $\mathrm{Ca}$ content using real experimental data (Khosroabadi et al., 2002), (Han et al., 2001), (Baetzold, 1988) about change in lattice parameters and oxygen content in $\mathrm{Y}_{1-x} \mathrm{Ca}_{x} \mathrm{Ba}_{2} \mathrm{Cu}_{3} \mathrm{O}_{7-\delta}$.

\section{THEORETICAL}

The substitution of different amounts of atoms of $\mathrm{Ca}$ in the superconductor $\mathrm{Y}_{1} \mathrm{Ca}_{x} \mathrm{Ba}_{2} \mathrm{Cu}_{3} \mathrm{O}_{7-\delta}$ on the structure of it (Iguchi et al., 1988), (Giri et al., 2005), (Han et al., 2001), greatly studied. It may be noticed that the lattice constant $\left(a_{p a}\right)$ increases with increasing $\mathrm{Ca}^{2+}$ content while lattice constant $b$ and $c$ changes slightly. On the other hand, the addition of $\mathrm{Ca}^{2+}$ at $\mathrm{Y}^{+3}$ site decreases slightly the difference between $\mathrm{a}$ and $\mathrm{b}$ parameters and thus reduces the orthorhombicity $(a-b) /(a+b)$ of $\mathrm{Y}_{123}$ phase, also, $\left(T_{c}\right)$ decreases with increasing Ca content this was also confirmed by AC susceptibility (Giri et al., 2005), from the references (Iguchi et al.,1988), (Giri et al., 2005), (Han et al., 2001) there are some data about the effect of addition of $\mathrm{Ca}$ to the superconductor $\mathrm{Y}_{1} \mathrm{Ca}_{x} \mathrm{Ba}_{2} \mathrm{Cu}_{3} \mathrm{O}_{7-\delta}$ on the $\left(\mathrm{T}_{c}\right)$ and (a, b, c) lattice parameters. In this research the first step is to find a relation between $\mathrm{EP},\left(T_{c}\right)$ and the lattice parameters. Also the relation between EP and orthorhombicity, volume parameter with increasing Ca must be found. To do the above steps first of all we calculate the distance between the Yttrium ion to all the other ions in the $\mathrm{Y}_{1} \mathrm{Ca}_{x} \mathrm{Ba}_{2} \mathrm{Cu}_{3} \mathrm{O}_{7-\delta}$ compound as seen in the figures $(1 \mathrm{a}, 1 \mathrm{~b})$ also it is important to consider the change in the distances between ions by the addition of $\mathrm{Ca}$ in $\mathrm{Y}_{1-x} \mathrm{Ca}_{x} \mathrm{Ba}_{2} \mathrm{Cu}_{3} \mathrm{O}_{7-\delta}$, then calculation of the electrostatic potential energy was done by using equation (1). From above calculation $\mathrm{EP}$ has been found for every content of $\mathrm{Ca}$ from (0 to 0.3$)$. The crystal model of the unit cel1 of $\mathrm{YBa}_{2} \mathrm{Cu}_{3} \mathrm{O}_{7-\delta}$. is shown in figure 1a, and figure 1b: shows the same crystal, but the 
crystal of $\mathrm{YBa}_{2} \mathrm{Cu}_{3} \mathrm{O}_{7-\delta}, \mathrm{YBCO}$ is so drawn such that it is shifted by (half diagonal of one of its cubes). That the $\mathrm{Y}$ and the $\mathrm{Ba}$ atoms are drowning on the edge of the crystal (Baetzold, 1988). The unit cell is orthorhombic with $\mathrm{N}=13$ atoms. The corresponding crystal structure, with the $\mathrm{a}$ and $\mathrm{b}$ axes differing by less than $2 \%$ generally $\mathrm{c}$ axis is parallel to the long cell dimension. The size of the unit cell has been found considering the lattice constants are $a=3.822 \AA, b=3.891 \AA$ and $c=$ $11.677 \AA$ A respectively.

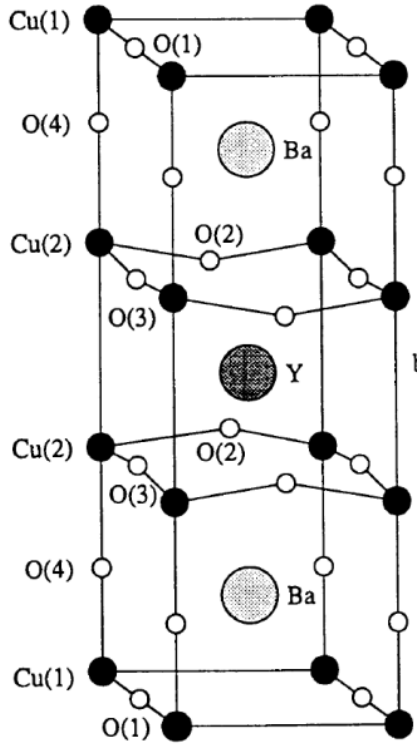

(1a)

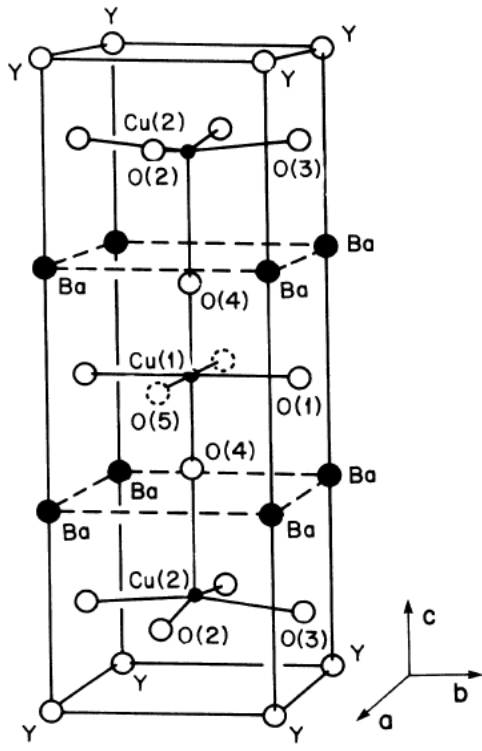

(1b)

Figs. (1a-1b): schematic diagram of two different model of crystal structure of YBCO compound (Baetzold, 1988), (Khosroabadi et al., 2002).

The $\mathrm{Cu}(2), \mathrm{O}(2)$, and $\mathrm{O}(3)$ atoms make up the superconducting $\mathrm{CuO}_{2}$ planes, which are important features of $\mathrm{Y}_{123}$ compounds. The $\mathrm{CuO}$ chains are believed to act as charge reservoirs. Between the $\mathrm{CuO}$ chains and $\mathrm{CuO}_{2}$ planes are the $\mathrm{O}(4)$ atoms commonly referred to as apical oxygen atoms.

Starting from the above model the sum of electrostatic potential energy EP of the $\mathrm{Y}^{3+}$ ion with charge $(+3 \mathrm{e})$ with all other ions of the crystal of charge $\left(q_{i}\right)$ depending on valence of the ions at distances $r_{i j}$ can be calculated easily from reference (Wright and Butler.,1990).

$$
E P=\frac{1}{4 \pi \epsilon_{0}}\left(N_{C a} N_{j}\right) \sum_{i}^{j}\left[\frac{q_{i,} q_{j}}{r_{i j}}\right] Z
$$

where $N_{C a}$ is the valence of the Ca ion, $N_{j}$ is the valence of the other element in the $Y_{1-x} \mathrm{Ca}_{x} \mathrm{Ba}_{2} \mathrm{Cu}_{3} \mathrm{O}_{7-\delta}$ compound, $q_{i}$ and $q_{i}$ are electric charges of $\mathrm{i}$ and $\mathrm{j}$ ions and equal to $1.6 \times 10^{-19}$ Coulomb and $E_{0}$ is electric permittivity in free space and $Z$ oxygen content in the $\mathrm{Y}_{1-x} \mathrm{Ca}_{x} \mathrm{Ba}_{2} \mathrm{Cu}_{3} \mathrm{O}_{7-\delta}$ compound.

Since $\mathrm{Ca}$ content changed we must consider the total change in the positions of atoms and also the change in charge. The oxygen content was taken from the relation between $\mathrm{Ca}$ content and oxygen content that obtained from figures in the references (Nazarova et al., 2004).

$$
Z=7-\frac{n_{C a}}{2}
$$

where $n_{C a}$ is $\mathrm{Ca}$ content and $\mathrm{Z}$ oxygen content in the $\mathrm{Y}_{1-x} \mathrm{Ca}_{x} \mathrm{Ba}_{2} \mathrm{Cu}_{3} \mathrm{O}_{7-\delta}$ compound. Also by using the relation from equation 2 reference (Nazarova et al., 2004). Y substitution by $\mathrm{Ca}$ was 
considered from equation 3 which combined the effect of change of valance $\left(N_{C a}\right)$, by addition of Ca content.

$$
N_{C a}=3\left(1-n_{C a}\right)+2 n_{C a}
$$

$N_{C a}$ is the valence of the $\mathrm{Ca}$ ion, also the ratio of oxygen content $R_{0}$ in the compound is calculated by using the equation:

$$
R_{0}=1-\left[\frac{7-Z}{4}\right]
$$

The hole concentraton $p_{h}$ can be calculated in the $\mathrm{CuO}_{2}$ plane of the $\mathrm{Y}_{1-x} \mathrm{Ca}_{x} \mathrm{Ba}_{2} \mathrm{Cu}_{3} \mathrm{O}_{7-\delta}$ compound by using the equation 5 taking from references (Schleicher et al.,1999), when the critical temperature $\left(T_{c}\right)$ and maximum critical temperature are known.

$$
p_{h}=0.16 \mp 0.11 \sqrt{1-\frac{T_{c}}{T_{c} \max }}
$$

$p_{h}$ is hole concentration, $\left(T_{c}\right)$ is the critical temperature and $\left(T_{c \max }\right)$ is the maximum critical temperature. By applying fitting method to figures $(2,3,4,5)$ we can determine the relation between electrostatic potential energy in the Y123 compound and $\left(T_{c}\right)$, Ca content, oxygen content, Volume parameter, and hole concentration.

Furthermore, the value of hole concentration obtained from the above equation is agreement with the plot of relation between the hole concentration and critical temperature as in reference (Naqib et al., 2009).

\section{RESULTS}

This research has investigated the effect of Ca content on crystal structure of superconductor, electrostatic potential energy, hole concentration and critical temperature in the YBCO compound. The result, will be shown in the following curves $(2,3,4,5,6,7,8)$.

Fig. (2-a): shows the EP and $\left(T_{c}\right)$ as a function of $\mathrm{Ca}$ content in $\mathrm{Y}_{1-x} \mathrm{Ca}_{x} \mathrm{Ba}_{2} \mathrm{Cu}_{3} \mathrm{O}_{7-\delta}$ compound the increase of Ca leads to decrease of ( $\left.T_{c}\right)$ (Giriet et al., 2005). The calculated values of $\mathrm{EP}$ with the increasing of $\mathrm{Ca}$ content in $\mathrm{Y}_{1-x} \mathrm{Ca}_{x} \mathrm{Ba}_{2} \mathrm{Cu}_{3} \mathrm{O}_{7-\delta}$ show corresponding changes are indicating a relation between change of charge content in the crystal.

Fig. (2-b): shows EP and $\left(T_{c}\right)$ as a function of the lattice parameter $\left(a_{C a}\right)$, with increase of calcium content in $\mathrm{Y}_{1-x} \mathrm{Ca}_{x} \mathrm{Ba}_{2} \mathrm{Cu}_{3} \mathrm{O}_{7-\delta}$ compound there is a good agreement in changes of both EP and $\left(T_{c}\right)$ with the lattice parameter $\left(a_{C a}\right)$.

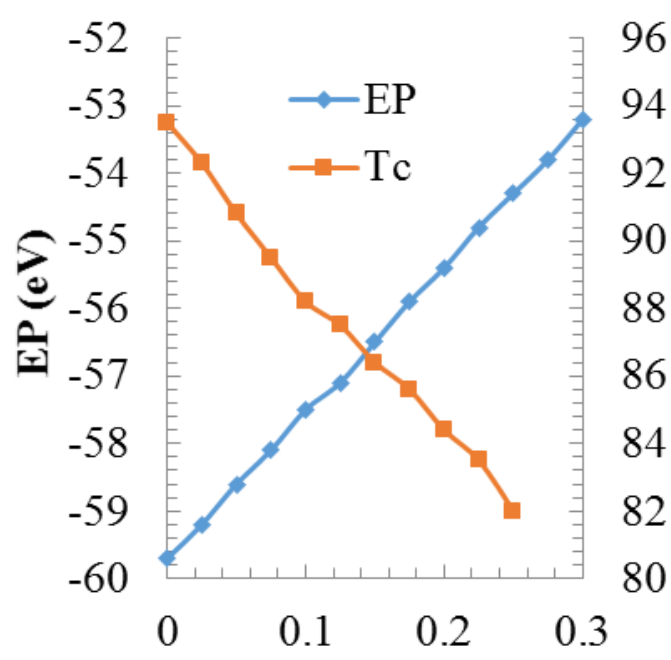

Ca content (a)

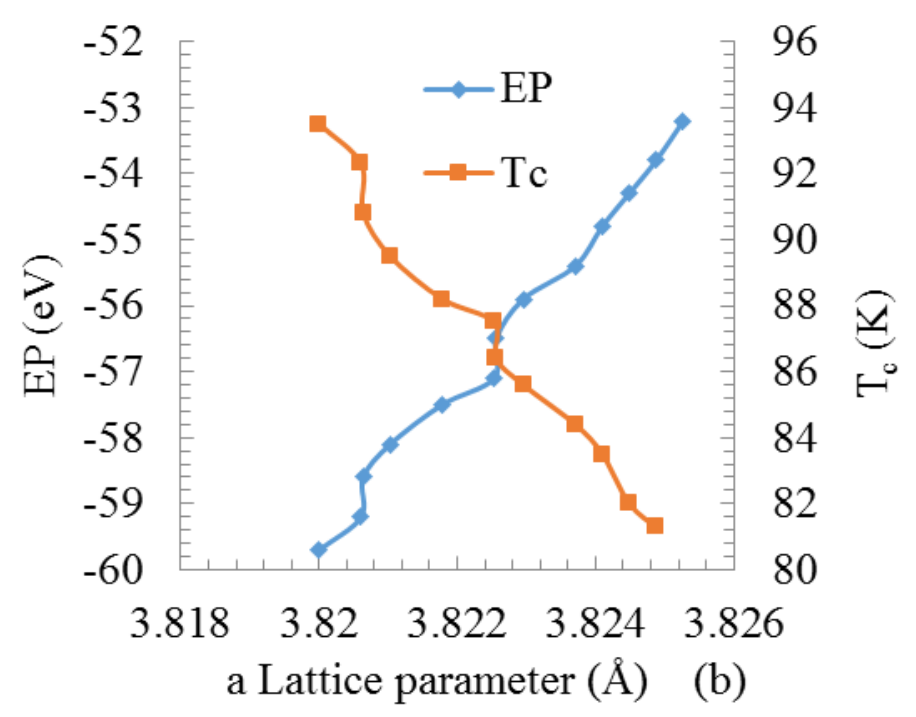


Fig. (2-a): The variation of EP and $\left(T_{c}\right)$ as a function of Ca content and Fig.(2-b): the variation of EP and $\left(T_{c}\right)$ as a function of lattice parameter $\left(a_{p a}\right)$.

The Fig.(3-a): shows EP and lattice parameter $\left(a_{p a}\right)$ as a function of Ca content in the $Y_{1-x} \mathrm{Ca}_{x} \mathrm{Ba}_{2} \mathrm{Cu}_{3} \mathrm{O}_{7-\delta}$ compound it is evident that there is an increase in EP and lattice parameter $\left(a_{p a}\right)$ with increasing of Ca content it is evident that there is a systematic relation between them.

Fig. (3-b): shows EP and the volume lattice parameter as a function of calcium content in $\mathrm{Y}_{1-x} \mathrm{Ca}_{x} \mathrm{Ba}_{2} \mathrm{Cu}_{3} \mathrm{O}_{7-\delta}$ compound it is evident that there is an increase in EP with the increasing of $\mathrm{Ca}$ content where there is a corresponding increase in the volume parameter it is evident that there is a systematic relation between them.

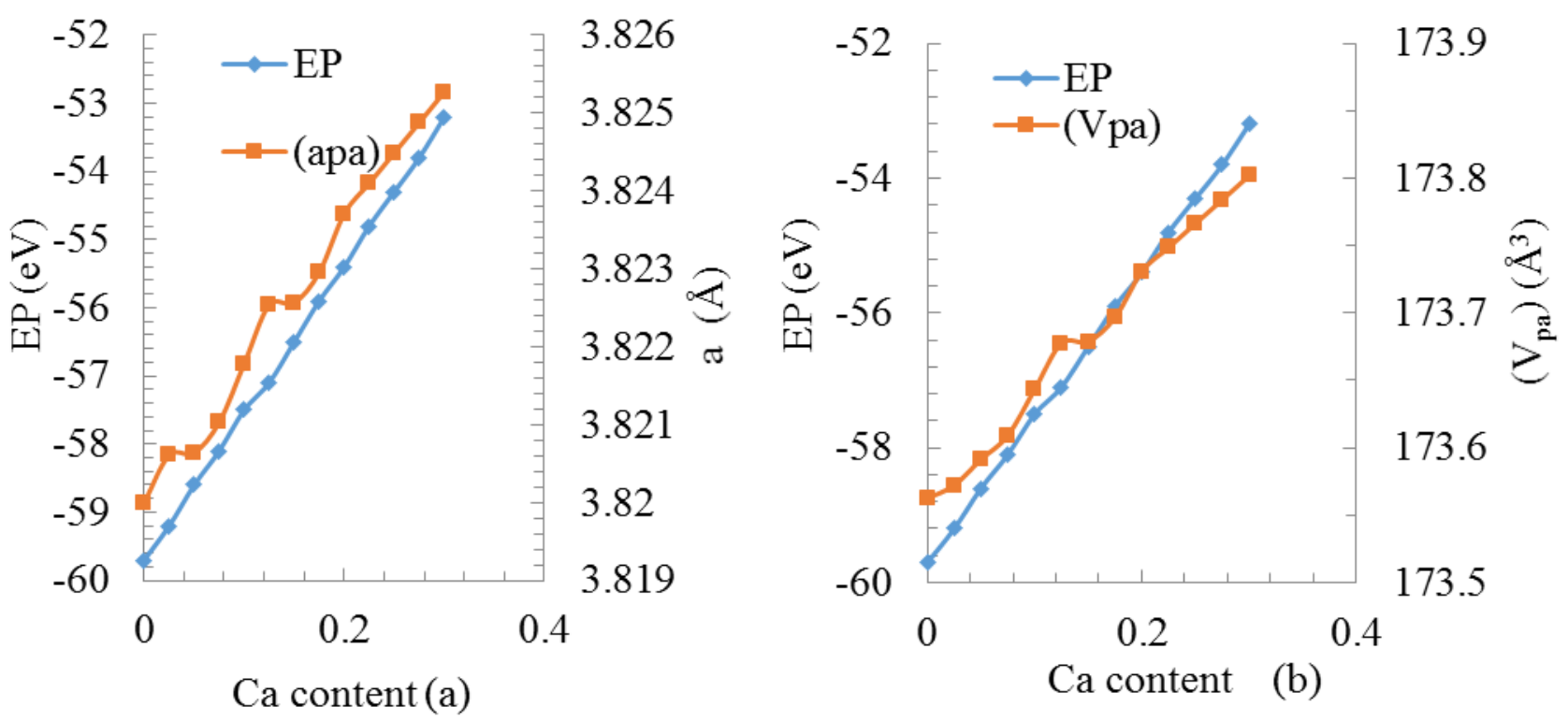

Fig. (3-a): The variation of EP and lattice parameter $\left(a_{p a}\right)$ and Fig.(3-b): the variation of EP and volume lattice parameter as a function of Ca content.

In Fig. (4): the EP and orthorhombicity of $Y_{1-x} \mathrm{Ca}_{x} \mathrm{Ba}_{2} \mathrm{Cu}_{3} \mathrm{O}_{7-\delta}$ compound as a function of calcium content in $\mathrm{Y}_{1-x} \mathrm{Ca}_{x} \mathrm{Ba}_{2} \mathrm{Cu}_{3} \mathrm{O}_{7-\delta}$ compound there is increasing of EP and decreasing of orthorhombicity with increases of $\mathrm{Ca}$ content in the compound. The sharp decrease of orthorhombicity in the beginning is due to the sharp change in lattice parameter $\left(a_{p a}\right)$, after 0.05 concentration there is a linear decrease with EP.

From Figs. (2, 3 and 4) many important relations between electrostatic potential and superconducting parameters can be found and we can derive a fitting relations between them 


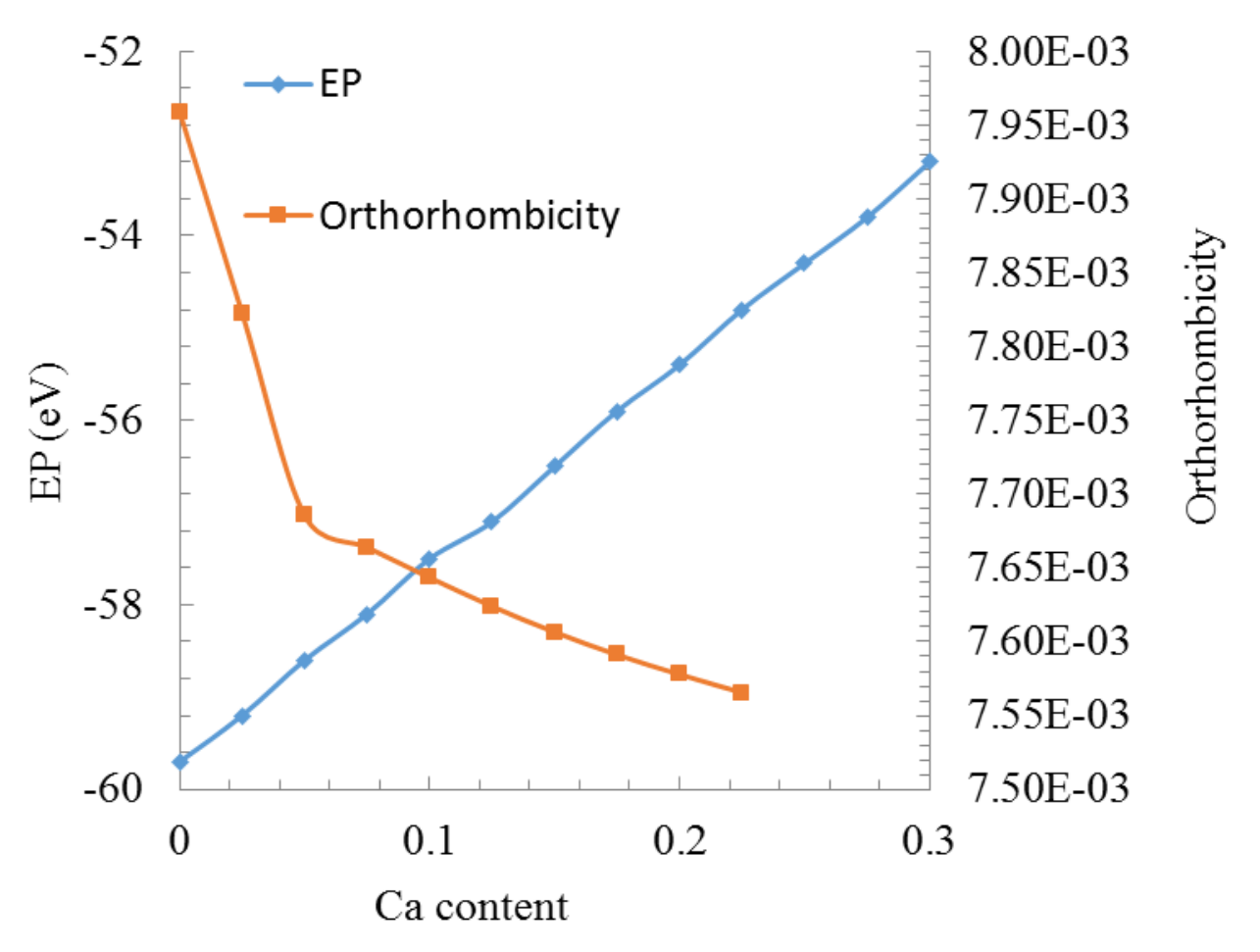

Fig. (4): The variation of EP and orthorhombicity as a function of Ca content

From Figs. (2, 3 and 4) many important relations between electrostatic potential and superconducting parameters can be found and we can derive a fitting relations between them.

Fig. (5-a): shows a good relation between $\mathrm{Ca}$ content and the electrostatic potential energy with correlation factor $\mathrm{R}=0.990$ the fitted relation is:

$$
E P=-12.64 n_{C a}+59.71
$$

Fig. (5-b): shows a good relation between lattice parameter $\left(a_{p a}\right)$ and electrostatic potential energy with $\mathrm{R}=0.988$ and with fitting relation:

$$
E P=-1191 a_{C a}+4610
$$

Fig. (6-a): is the relation between volume lattice parameter and electrostatic potential energy and correlation factor $\mathrm{R}=0.99$ with fitting relation:

$$
E P=-25.65 V_{p a}+4511
$$

$V_{p a}$ is volume lattice parameter.

Fig. (6-b): shows the relation between orthorhombicity and electrostatic potential energy in polynomial form with $\mathrm{R}=0.96$ and relation:

$$
E P=6 \times 10^{7 \theta^{2}}+87957 \theta+3396
$$

$\Theta$ is orthorhombicity of compound. 

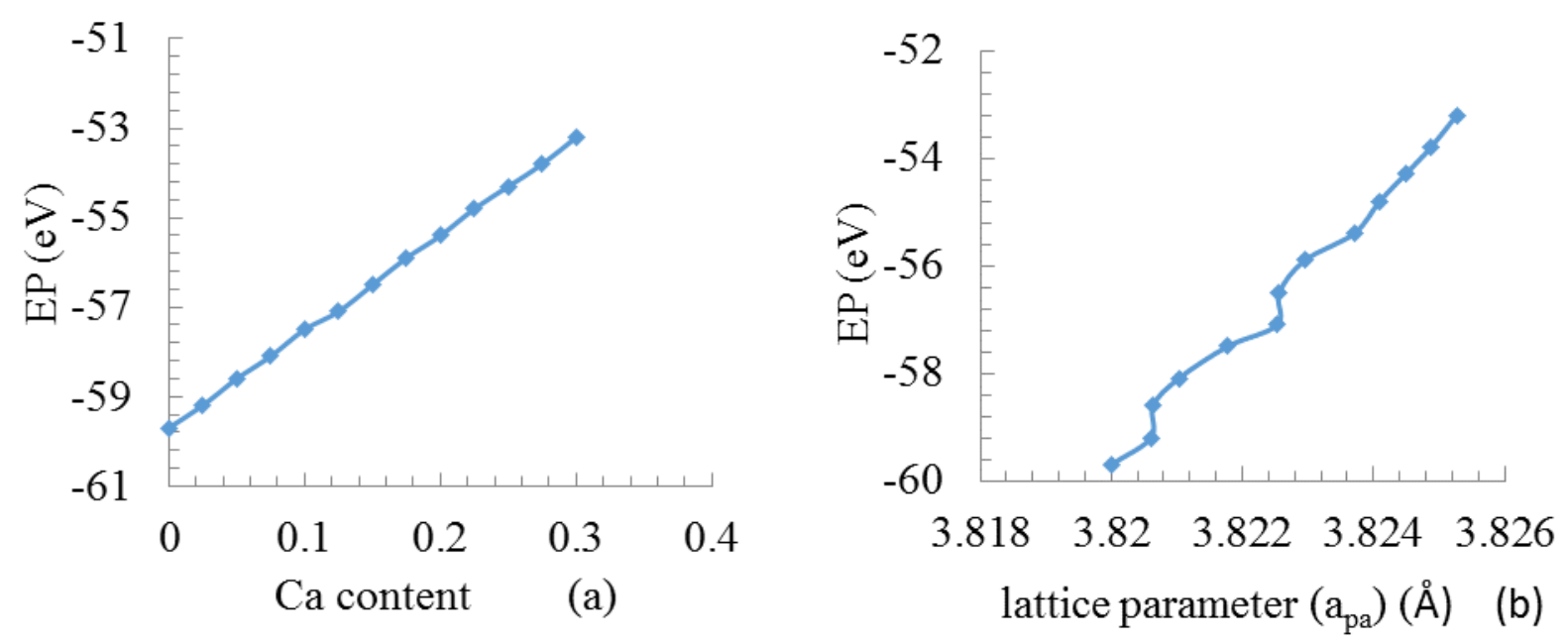

Fig. (5-a): The variation of EP as a function of Ca content and Fig. (5-b): the variation of EP as a function lattice parameter $\left(a_{p a}\right)$ in $\mathrm{Y}_{1-x} \mathrm{Ca}_{x} \mathrm{Ba}_{2} \mathrm{Cu}_{3} \mathrm{O}_{7-\delta}$.

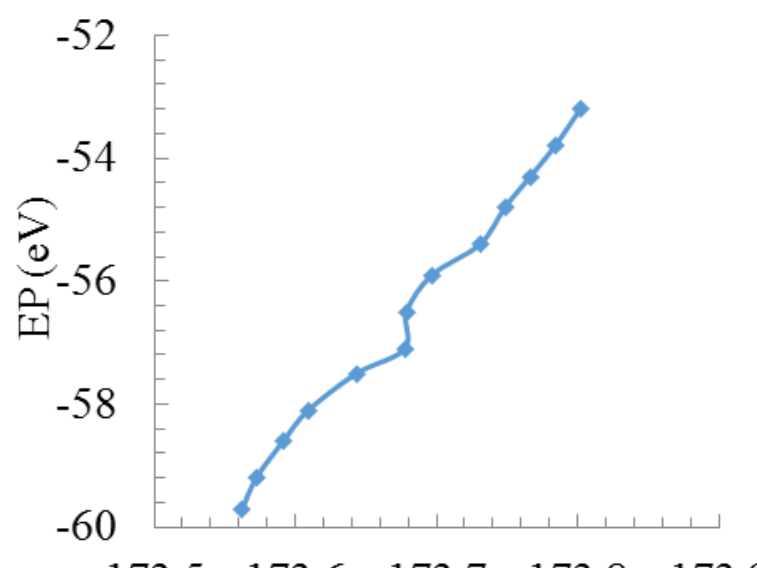

$\begin{array}{lllll}173.5 & 173.6 & 173.7 & 173.8 & 173.5\end{array}$

$$
V_{p a}(\AA)^{3} \quad \text { (a) }
$$

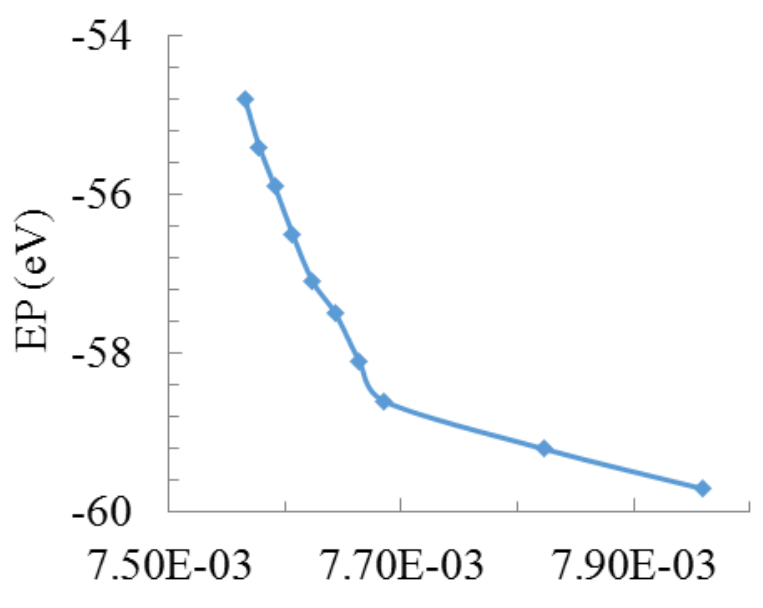

Orthorhombicity (b)

Fig. (6-a): The variation of EP as a function of volume lattice parameter $\left(V_{p a}\right)$ and Fig.(6-b): the variation of EP as a function of orthorhombicity.

Fig.(7-a): shows the relation between Ca content and hole concentration, the dependence is logarithmic with $\mathrm{R}=0.98$ and the relation is:

$$
p_{h}=0.011 \operatorname{Ln}\left(n_{C a}\right)+0.212
$$

$p_{h}$ is hole concentration in $\mathrm{CuO}_{2}$ plane.

Fig. (7-b): shows the relation between the hole concentration and electrostatic potential energy in polynomials with $\mathrm{R}=0.996$ and relation

$$
E P=4393 p_{h}^{2}-1433 p_{h}+57.135
$$

In Fig.(8-a): shows that as critical temperature is increasing the electrostatic potential energy decrease and we can determine the relation between EP and $\left(T_{c}\right)$ from data fitting obtained from figure (8-a) that as in the equation (12) 


$$
E P=-0.4877 T_{c}-14.28
$$
content.

Shown the dependence of both the electrostatic potential energy and hole concentration on $\mathrm{Ca}$

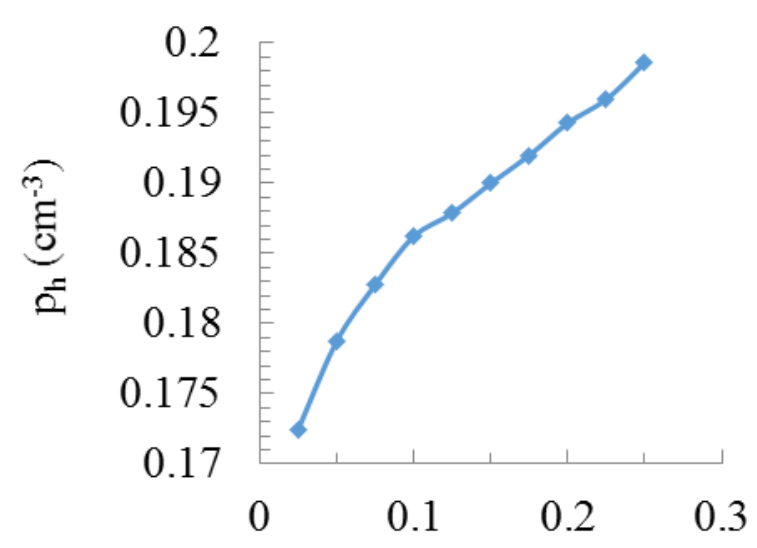

Ca content (a)

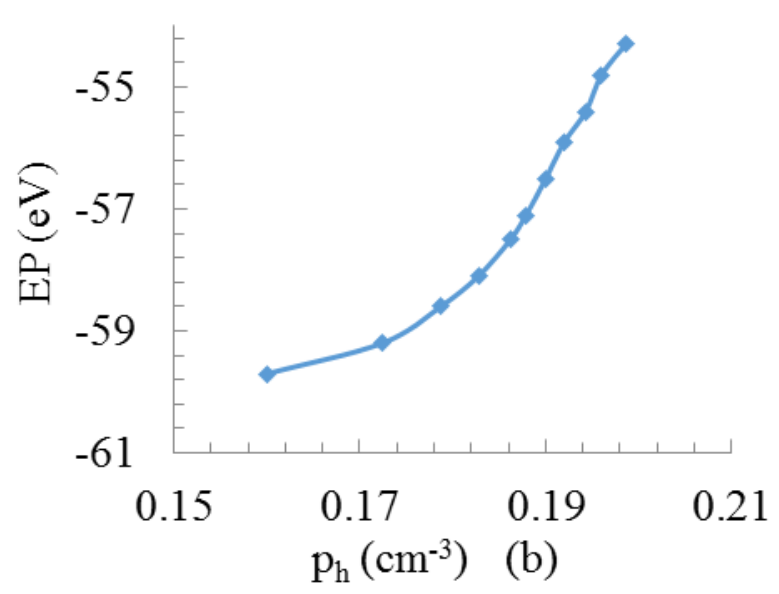

Fig. (7-a): The variation of hole concentration as a function of Ca content and Fig. (7-b): the variation of $\mathrm{EP}$ as a function of hole concentration.

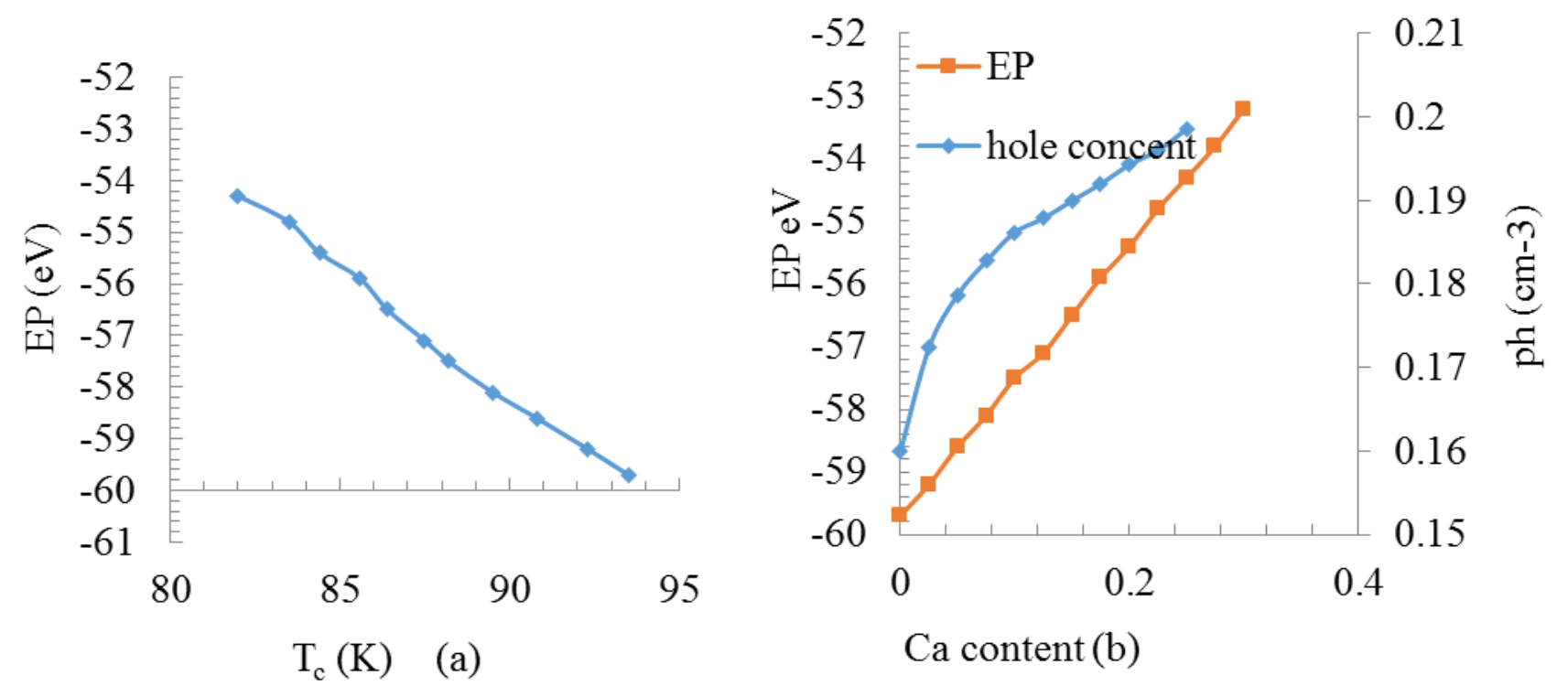

Fig. (8-a): The variation of EP as a function of $T_{c}$ and Fig. (8-b): the variation of EP and hole concentration as a function Ca content.

\section{DISCUSSION}

With Y substitution by the calcium, the critical temperature and other superconducting parameters such as lattice parameter $\left(a_{p a}\right)$, volume lattice parameter $\left(V_{p a}\right)$ and orthorhombicity will be changing. In this work we proved that there is a very good correlation $\mathrm{R}=0.990$ between $\mathrm{Ca}$ content in compound and the electrostatic potential energy with linear relation (equation 6). Furthermore good relation between EP and lattice parameter $\left(a_{p a}\right)$ in relation (equation 7) and also $\left(V_{p a}\right)$ and EP from (equation 8). And finally orthorhombicity and EP (equation 9). According to the crystal model of Fig.(1), replacement of $\mathrm{Y}^{+3}$ by $\mathrm{Ca}^{2+}$ would increase the $\mathrm{PE}$ due to two factors, one is decreasing of charge from +3 to +2 and increasing the ionic radius from the small ionic radii $\mathrm{Y}^{+3}(1.019) \AA$ by the large ionic radii of $\mathrm{Ca}^{+2}(1.12) \AA$. The big ionic radius $\mathrm{Cf}^{2+} \mathrm{Ca}^{2+}$ and weak 
coulomb attraction will increase the lattice constant $\left(a_{p a}\right)$. Substitution by $\mathrm{Ca}^{2+}$ increases number of holes in the $\mathrm{CuO}_{2}$ plane. At the same time oxygen content in $\mathrm{CuO}$ chain decreases (Gir et al., 2005), (Han et al., 2001), because $\mathrm{Ba}$ ions become nearer to the $\mathrm{Ca}^{2+}$ and thus nearer to the $\mathrm{CuO}_{2}$ plane this is due to the increase of EP. Also the decrease of the $\left(T_{c}\right)$ can be explained as due to decrease of oxygen because increase of the EP means loosing of the ionic bonds between central ion and other ions of the crystal. All above effects lead to increase the holes in the $\mathrm{CuO}_{2}$ plane due to replacement of the $\mathrm{Y}^{3+}$ by $\mathrm{Ca}^{2+}$ and transfer of holes from $\mathrm{CuO}_{2}$ plane to $\mathrm{CuO}$ chain (Giri et al., 2005), ( Singh et al., 2012).

From Fig. (7-b) shows direct dependence of hole concentration ions and EP this may explain the experimental facts that current increases with increasing $\mathrm{Ca}$ in $\mathrm{YBCO}$.

\section{CONCLUSIONS}

$\mathrm{Ca}^{2+}$ substitution for $\mathrm{Y}^{3+}(0-0.3)$ leads to increase EP which caused by increasing ions volume and decreasing of charge, this explains change of superconducting structure parameters such as: lattice parameter $\left(a_{p a}\right)$, volume parameter $\left(V_{p a}\right)$ and orthorhombicity.

$\left(T_{c}\right)$ decreases, with increasing $\mathrm{Ca}$ content due to the disorder in the superconducting $\mathrm{CuO}_{2}$ planes with Ca doping due to increase of EP which leads to flattening of the $\mathrm{CuO}_{2}$.

Increases of EP lead to change of the crystal structure and thus decreasing oxygen content and as a result decreasing of $\left(T_{c}\right)$.

$\mathrm{Ca}^{2+}$ substitution for $\mathrm{Y}^{3+}$ increases the overall hole concentration, this substitution effect, first takes place in $\mathrm{CuO}_{2}$ planes and also because oxygen removing from $\mathrm{CuO}_{1-\delta}$ chains. to compensate the additional effect of $\mathrm{Ca}$ current. These results will increase the superconducting current although the $\left(T_{c}\right)$ was decreasing.

\section{REFERENCES}

Baetzold, R.C. (1988). Atomistic simulation of ionic and electronic defect in $\mathrm{YCa}_{x} \mathrm{Ba}_{2} \mathrm{Cu}_{3} \mathrm{O}_{7}$. PHYS. Rev. B., 38(16). pp. 1041-1045

Giri, R.; Singh, H.K.; Srivastava, O.N.; Awana, V.P.S.; Gupta, A.; Kumaraswamy, B.V.; Ishan, H. (2005). Effect of Ca doping for $\mathrm{Y}$ on structural / microstructural and superconducting properties of $\mathrm{Y}_{1} \mathrm{Ca}_{x} \mathrm{Ba}_{2} \mathrm{Cu}_{3} \mathrm{O}_{7-\delta}$. Phys $C$. Supercond and its application. 419 (3-4). pp.101-108.

Han, HA.D.; Min, H.S.; Won Lee, K. (2001). Effects of Cation Substitution on the Oxygen Lossin YBCO Superconductors. J. Korean Phys. Soci, 39(6).

Iguchi, K.; Soga, Y.; Ando, K.; Saito, T.; Shinagawa, K.; Tsushima, T. (1988). Oxygen Deficiency $\delta$ and Its Effect on Tc In Superconducting $\mathrm{Y}_{1} \mathrm{Ca}_{x} \mathrm{Ba}_{2} \mathrm{Cu}_{3} \mathrm{O}_{7-\delta}$. J. DE PHYSIQUE Colloque C8. 49(12).

Jian, WU. Z; Qing, M.; Siyuan, Z. (1998). Valence of Cu in $Y_{1-y} C a_{x} B a_{2} C u_{3} O_{6+y}$. CHIN. PHY C. LETT. 15(7). 528 p.

Khosroabadi, H.; Mohammadi Zadeh, M.R.; Akhavan, M. (2002). Structural and properties of $\mathrm{YCa}_{x} \mathrm{Ba}_{2} \mathrm{Cu}_{3} \mathrm{O}_{7}$ under high pressure. Physica, 370, pp. 85-93.

Liyanawaduge, N.P.; Kumar, A.; Kumar, Sh.; Karunarathne, B.S.B.; Awana, V.P.S. (2012). The role of $\mathrm{Ca}$ in superconducting and magnetic properties of $\mathrm{Y}_{1-\mathrm{y}} \mathrm{Ca}_{\mathrm{y}} \mathrm{Ba}_{2} \mathrm{Cu}_{3} \mathrm{O}_{7-\delta}(\mathrm{x}=0.0-$ 0.30). J. Supercond and Nov. Magn., 25, pp. 31-37.

McCormack, R.; de Fontaine, D. (1992). Oxygen configurations and their effect on charge transfer in off-stoichiometric $\mathrm{YCaBa}_{2} \mathrm{Cu}_{3} \mathrm{O}_{\mathrm{z}}$. PHYS. REV. B., 45(22). 
Naqib, S.H.; Cooper, J.R.; Loram, J.W. (2009). Effects of Ca substitution and the pseudogap on the magnetic properties of $Y_{1-x} \mathrm{Ca}_{x} \mathrm{Ba}_{2} \mathrm{Cu}_{3} \mathrm{O}_{7-\delta}$. PHYS. REV B., 79, $104519 \mathrm{p}$.

Nazarova, E.K.; Zaleski, A.J.; Zahariev, A.L.; Stoyanova-Ivanova, A.K.; Zalamova, K.N. (2004). Effects of substituting calcium for yttrium on the superconducting properties of $\mathrm{YBa}_{2} \mathrm{Cu}_{3} \mathrm{O}_{\mathrm{z}}$ bulk samples. Physica C. Supercond. 403(4), pp. 283-289.

Schleicher, S.I.; Fietza, W.H.; Grubea, K.; Wolfa, Th.; Obst, B.; Schweiss, P.; Klaser, M. (1999). The Effect of Chemical Doping and Hydrostatic Pressure on $\mathrm{T}_{\mathrm{c}}$ of $\mathrm{Y}_{1-y} \mathrm{Ca}_{y} \mathrm{Ba}_{2} \mathrm{Cu}_{3} \mathrm{O}_{x}$ Single Crystals. Physica C. 328(1-2).

Sedky, B.; Abu-Ziad, B. (2010). New investigation to $\mathrm{T}_{\mathrm{c}}$ depression by $\mathrm{Ca}$ in $\mathrm{Y}_{1-}$ ${ }_{\mathrm{x}} \mathrm{Ca}_{\mathrm{x}}$ :123Superconducting system. Physica $C$, 470, pp. 659-668.

Singh, S.K.; Husain, M.; Awana, V.P.S. (2012). Structure and Charge transfer Mechanism in $\mathrm{Y}_{1-y} \mathrm{Ca}_{y} \mathrm{Ba}_{2} \mathrm{Cu}_{3} \mathrm{O}_{7-\delta}$ through direct doping. J. Supercond. Nov. Magn., 25, pp. 17011706.

Wright, N.F.; Butler, W.B. (1990). Ionic model for the stability of the Y-Ba-Cu hightemperature superconducts. Phys. Rev. B., 42(7), pp. 4219-4227.

Wu, Z.J.; Meng, Q.B.; Zhang, S.Y. (1998). Semi empirical study on the valences of $\mathrm{Cu}$ and bond covalency in $\mathrm{Y}_{1-y} \mathrm{Ca}_{\mathrm{y}} \mathrm{Ba}_{2} \mathrm{Cu}_{3} \mathrm{O}_{7}$. PHYS. REV. B., 58(2).

Zhao, G.M. (2005). Pairing interactions and pairing mechanism in high-temperature copper oxide superconductors. PHYS . REV. B., 71, 104517 p. 